\title{
Whose Absentee Voters are Counted: The Variety and Use of Absentee Ballots in California
}

\author{
R. Michael Alvarez \\ Thad E. Hall \\ D. E. "Betsy" Sinclair †
}

January 24, 2005

$\dagger$ Professor of Political Science, California Institute of Technology, rma@hss.caltech.edu; Assistant Professor of Political Science, University of Utah, thad.hall@csbs.utah.edu; and Graduate Student, California Institute of Technology, betsy@hss.caltech.edu.

We thank Los Angeles County Registrar Recorder Conny McCormack and her staff for access to data from the 2002 election. We also thank Mary Sikora for her assistance, and Steve Ansolabehere for his assistance on a related project. Participants at a seminar presented by Hall at Brigham Young University provided helpful comments to an earlier version of this paper. Alvarez's research was supported by the Carnegie Corporation of New York, by grants to the Caltech/MIT Voting Technology Project, and by the IBM Corporation. 


\section{Abstract}

Absentee voting is becoming more prevalent throughout the United States. While there has been some research focused on who votes by absentee ballot, little research has considered another important question about absentee voting: Which absentee ballots are counted and which are not? Research following the 2000 presidential election has studied the problem of uncounted ballots for precinct voters but not for absentee voters. Using data from Los Angeles County - the nation's largest and most diverse voting jurisdiction - for the November 2002 general election, we test a series of hypothesis that certain types of ballots and voters have a higher likelihood that their ballots will be counted. We find that uniform service personnel, overseas civilians, voters who request non-English ballots and permanent absentee voters have a much lower likelihood of returning their ballot, and once returned, a lower likelihood that their ballots will be counted compared with the general absentee voting population. We conclude our paper with a discussion of the implications of our research for the current debates about absentee voting. 


\section{Introduction}

In recent years there has been a dramatic liberalization of absentee voting laws throughout the United States. For example, in California before 1978, only registered voters who were disabled, ill, or for other documented reasons could not get to a polling place on election day could vote absentee; after 1978, any registered California voter could vote absentee without a documented cause. In the 1978 California general election, 314,258 absentee votes were cast ( $4.41 \%$ of all votes cast); but by the 2002 general election, 2,096,094 absentee votes were cast $\left(27.09 \%\right.$ of all votes cast). ${ }^{1}$ Another example is Oregon, widely considered a leader in absentee voting. In 1998, 58\% of the votes cast in their general election were absentee ballots, but following the passage of Ballot Measure 60 in 1998, all of Oregon's statewide elections are now conducted by mail. The United States Census Bureau estimated that at least $14 \%$ of votes cast in the 2000 presidential election were absentee or early votes. ${ }^{2}$

But absentee voting, especially the liberalization of voting-by-mail, is not without critics. Some have criticized "by demand" absentee voting (in contrast to "by need" absentee voting) because of fears about voter coercion, the lack of privacy, and the potential for fraud (Caltech/MIT Voting Technology Project 2001). Others have criticized absentee voting as a mechanism that undermines civic values and might lead voters to cast less informed ballots, as the early voters do not have access to late-breaking campaign information (Ornstein 2001). There is also a healthy academic debate about whether or not the presence of liberalized absentee voting procedures, like those in Oregon, help fuel a long-term increase in voter turnout (Aldrich 1993; Berinsky et al. 2001; Southwell and Burchett 2000a).

A large descriptive literature exists on the history of absentee voting laws and the

\footnotetext{
${ }^{1}$ For a more detailed discussion of the early changes in California's absentee voting procedures and their impact see Patterson and Caldeira (1985).

${ }^{2}$ We say "at least" because the Census estimate does not include overseas citizens or military personnel overseas. In addition to universal absentee voting in Oregon, the use of absentee balloting was high in Washington (52\%); Colorado, Nevada and Arizona (roughly 35\%); and New Mexico and California (22\%). See U.S. Census Bureau (2002).
} 
potential impact they had on election outcomes (APSA 1952; Keyssar 2000; Martin 1945; Ray 1926, 1919, 1918a, 1918b, 1914; Steinbicker 1938; Winther 1944). In recent years, research has focused on the factors that lead to increases in absentee voting (e.g. Dubin and Kalsow 1996a, 1996b; Oliver 1996; Patterson and Caldeira 1985), the impact of absentee voting and other electoral procedures on overall voter participation (e.g., Kim et al. 1975; Oliver 1996, Rosenstone and Hansen 1993; Wolfinger and Rosenstone 1980, Stein and Garcia-Monet 1997), the characteristics of absentee voters (Stein 1998), and the impact of having the entire population of a jurisdiction vote absentee - as occurs in Oregon - on overall voter turnout (Berinsky et al. 2001; Karp and Banducci 2000; Southwell and Burchett 2000a, 2000b, 1997). There are also normative arguments regarding whether absentee voting has other broader impacts on civic values and the political process (e.g., Gans 2000; Ornstein 2001).

The research literature tends to focus on a single aspects of the absentee voting process - the actual casting of ballots using the typical absentee voting method, also known as bymail voting or postal voting. However, as the 2000 general election showed, the decision by the voter to cast an absentee ballot is only one aspect of the voting process. After the ballot is cast, there is a second decision that is made primarily by election officials, who have to determine whether the ballot cast should be counted. For a variety of reasons, many absentee ballots (as well as ballots cast in-person at poll sites on Election Day) are not included in the vote tabulation process. Absentee ballots can be excluded from final tabulation for a variety of reasons: the ballot is returned to the local election official after the deadline for accepting such ballots, the information on the outside of the absentee ballot (which validates its authenticity), is not completed entirely or appears incorrect, the voter's eligibility to cast such a ballot is challenged, or the ballot is spoiled in some way. ${ }^{3}$

\footnotetext{
${ }^{3}$ Ballots that are not included in vote tabulation are sometimes called "disqualified" ballots (GAO 2001). Excluded or disqualified ballots are not included in their entirety in vote tabulation; this is in contrast to "residual votes", which are ballots on which no votes are counted for specific races because the voter did not make a discernable indication of preference ("undervotes"), or make more indications of preference than allowed ("overvotes"). For studies of the latter "uncounted" votes, see Alvarez and Sinclair (2004), Ansolabehere (2002), and Tomz and Van Houweling (2003).
} 
This second part of the absentee voting process - the decision whether or not particular absentee ballots are included in final election tabulation - has been ignored in the research literature. As increasing numbers of ballots are being cast using the absentee process, it is important to understand how many absentee ballots are not being counted and who is casting these uncounted ballots.

Thus, our research focuses on this unanswered question about absentee voting. Which absentee ballots are counted, and which are not? To answer this question we use data from Los Angeles County - the nation's largest and most diverse voting jurisdiction for the November 2002 general election to examine both of these questions. In the next section we discuss the specifics of our absentee voting dataset and the hypotheses we test. Then we turn to our empirical results, and we conclude with a discussion of the implications of our research for the current debates about absentee voting.

\section{Studying Absentee Voting in Los Angeles County}

In the empirical analysis we present below we use the "absentee voter file" (AVF) from Los Angeles County's November 2002 general election. This file has a record for every

eligible absentee voter: all permanent absentee voters, all those in vote-by-mail districts, all of the overseas civilians and military personnel voters, and all others who did not cast a ballot in a traditional polling place. The AVF records the process used by each absentee voter to request a ballot; it also records two aspects regarding the resolution of the ballot request: (1) whether the absentee ballot was returned or not, and (2) if it was returned whether it was included in the vote tabulation. The AVF also records basic voter registration and absentee voting information, like party registration, birthdate, and ballot language. We discuss the details of the specific AVF records that are part of our study below.

Los Angeles County, California, is the largest and most complex election jurisdiction in the United States. In the November 2002 general election, there were almost 4 million registered voters in Los Angeles County, and almost 5000 voting precincts. There were al- 
most 1.8 million ballots cast in the November 2002 election, with almost 390,000 of them coming from absentee voters. In Los Angeles County, election officials are required to provide all elections materials in six languages in addition to English: Chinese, Japanese, Korean, Spanish, Tagalog, and Vietnamese. This election cost more than $\$ 20$ million dollars in administrative costs alone. In California, absentee ballots are due on Election Day. Voters can either mail the ballot-which has to be received by-mail by the registrar by 8:00 pm on Election Day-or can be delivered to the polling place by a voter and placed in the ballot box. The process of counting and processing absentee ballots is open to observation by interested parties and citizens, and is laid forth in California Code Section 15100-15112.

The complexity of election administration in Los Angeles County make it an important case for study. With the large number of absentee voting requests and ballots cast, we have sufficient data to study statistically what in other election jurisdictions might be slivers of the voting population; for an important example, overseas civilian and military personnel. Thus, the sheer size of Los Angeles County's absentee voting population provides us with more statistical power than we could gain by studying other election jurisdictions. Second, the political and social diversity of Los Angeles County provides us the opportunity to study additional questions about absentee voters, especially in our case the relative ease with which non-English speaking citizens can use the absentee voting process.

On the other hand, studying only Los Angeles County has limitations. The most important limitation of our analysis is our focus on one large and urban California county. Thus, given the unique characteristics of Los Angeles County and the specific nature of California's election laws (especially those governing absentee voting), we must be cautious about extrapolating from our results to other election jurisdictions.

\section{Previous Research and Hypothesis}

One aspect of the absentee voting process that has not been studied in the research literature are the many ways in which citizens (here California citizens) can vote outside the 
polling place. ${ }^{4}$ First, there is the type of absentee voting that is commonly associated with the practice: a registered voter completes an absentee ballot form (provided in their sample ballot, or by third parties like candidates or political organizations) and either sends it to their county election official or drops it off at an election office; these voters receive their ballot later by mail, and either return it in the mail, drop it off in person at an election office or at a polling place on election day, or have an authorized third party return it for them. In the AVF dataset these voters are separated into two categories - those who have mailed in their sample ballot to request an absentee ballot and those who have "applied by mail" via a third party to request an absentee ballot.

Second, there are permanent absentee voters. After registered voters request this status, they automatically receive absentee ballots in the mail; as long as they return their ballot in all statewide elections they retain their permanent absentee voter status. ${ }^{5}$ Under certain conditions voters can be required to vote by mail, at the discretion of the local election official: if the voter's election precinct has fewer than 250 registered voters on the $88^{\text {th }}$ day before an election, the precinct can be declared a "mail ballot precinct" and all voters in the precinct are automatically sent absentee ballots.

Third, overseas citizens and military personnel, formally covered by the "Uniformed Overseas Citizens Absentee Voting Act" (recently updated by the National Defense Authorization Act of 2002 and the Help America Vote Act of 2002), have an expedited and simplified registration and absentee ballot request process. These citizens can use the

\footnotetext{
${ }^{4}$ See "A Guide to Absentee Voting in California, 2001", California Secretary of State, Elections Division, http : //www.ss.ca.gov/elections/Outreach/absentee/links/absgde_long.pdf for additional details about absentee voting in California.

${ }^{5}$ Also, voters who obtain a court order showing necessary cause for their registration information to be kept confidential are categorized as a type of permanent absentee voter until the election official is informed that it is no longer necessary to keep the voter's identification confidential. These voters are denoted in this way in our dataset and are dropped from the analysis. This special class of absentee voters is covered in California Election Code Section 2166, which reads in part (Section 2166(a)): "Any person filing with the county elections official a new affidavit of registration or reregistration may have the information relating to his or her residence address, telephone number, and email address appearing on the affidavit, or any list or roster or index prepared therefrom, declared confidential upon order of a superior court issued upon a showing of good cause that a life threatening circumstance exists to the voter or a member of the voter's household..." Such registered voters will "Be considered an absent voter for all subsequent elections or until the county election official is notified otherwise by the court or in writing by the voter" (Section 2166(b)(1)).
} 
"Federal Postcard Application," which simultaneously serves as a voter registration and absentee ballot request, thus simplifying the process for this group. Also, citizens in this same group can request "special absentee voter" status; which, because of their location or duties makes it impossible for them to vote absentee during the required period. "Special absentee voters" receive their ballot approximately 60 days before the election; all other requests for absentee ballots made more than 29 days before the election are not processed until the $29^{\text {th }}$ day before the election.

A final category of absentee voters in California are those who because of illness, disability, or physical handicap are unable to vote at a precinct polling place and who have missed the application deadline for requesting an absentee ballot. ${ }^{6}$ These citizens can request an absentee ballot in writing which can be provided to an authorized representative of the citizen who presents the written application to an election official. The voter, or their authorized representative, can return the absentee ballot to an election official or to any polling place in the election jurisdiction. ${ }^{7}$

These various categories of absentee voting show how voters make a series of choices about whether they want to vote and how they want to vote. Research on absentee voting has traditionally focused on the behavioral decision by registered voters whether to cast their ballot in the polling place or by some absentee method, and has focused on the relative differences between absentee voters, precinct voters, and non-voters, usually employing survey data. There has been little attention focused on the different types of absentee voters or on the important political question of whose absentee ballots are returned and then counted.

The latter is a critical question, highlighted by studies of voting in the wake of the

\footnotetext{
${ }^{6}$ In the 2002 election there was another category of absentee voters: those who voted in a special preelection period, in person, using electronic touchscreen voting systems. This was the result of a special pilot project in Los Angeles County; we consider these as early voters, and they are not included in our analysis below. For research on early voting, see Stein and Garcia-Monet (1997) and Stein (1998).

${ }^{7}$ One final note on the classifications of absentee voters is that in 2002 Los Angeles permitted voters to go to a select group of polling places before the election and cast a vote on a touchscreen machine. Because these voters cast early ballots, and because they did in fact vote in a polling place (although not on election day) we drop them from our analysis even though they are also included in the AVF.
} 
2000 presidential election (e.g., Alvarez and Sinclair 2004; Caltech/MIT 2001; Tomz and Van Houweling 2003). Despite conventional wisdom, casting an absentee ballot is not the same as casting a vote at the polls as the voter does not place their ballot in a box or in the memory of an electronic voting machine. Instead, they mail their ballot or deliver it to an election official, and are rarely certain how the ballot is adjudicated.

Absentee ballots can be challenged and not counted in the certified results for a variety of reasons. The most likely reason why a ballot is rejected is that it is received after the close of the polls. For example, in California absentee ballots have to be received by the election officials by the close of the polls on Election Day. However, even if a ballot is received in time, it can be challenged for other reasons. When the election official receives a ballot, all of the information on the outside of the ballot that authenticates the ballot is examined. A voter is required to sign the ballot envelope and provide other information, such as their address. If the signature does not match or is missing, or the other information does not match what is on file, the ballot is also rejected. ${ }^{8}$

Voting for certain absentee populations is also more difficult. Recent studies by the US General Accounting Office (2001) show that casting a meaningful absentee vote can be very difficult for individuals who are UOCAVA voters. One key problem is ballot transit time; a 2001 GAO study found that transit times for first class mail can range from as little as five days to as much as a month (GAO 2001). Additionally, all voters - including UOCAVA voters - make errors in completing the forms required for an absentee ballot request. As the GAO noted,

Military and overseas voters do not always complete absentee voting requirements or use federal forms correctly. The basic steps that absentee voters must take to register and request an absentee ballot are similar for all states. Nevertheless, absentee voting schedules and requirements vary from state to state. In addition, counties vary in how they interpret and implement state

\footnotetext{
${ }^{8}$ See Hall (2002) for a detailed discussion of the ballot reconciliation and certification process used in Los Angeles.
} 
requirements... varying state and county requirements resulted in confusion among voters about residency requirements and about the deadlines for registering to vote, requesting a ballot, and returning the voted ballot. County officials said that problems in processing absentee voting applications arise primarily because voters do not fill in the forms correctly or do not begin the voting process early enough to complete the multiple steps they must take (GAO 2001, pages 40-41).

In a recent significant study, similar to ours, Imai and King (2004) examined late overseas absentee ballots received in the 2000 Florida election after November 7, 2000, which county canvassing boards deliberated over between November 17 and November 26. Imai and King (2004) examined 3739 overseas ballots, of which 2490 were accepted and counted by canvassing boards; thus, $33 \%$ of the overseas ballots received in Florida after November 7, 2000 were invalidated for various reasons.

Importantly, Imai and King (2004) studied the 2490 overseas absentee ballots received after November 7, 2000, which were accepted by canvassing boards and included in their county tabulations. Based on their understanding of the Florida regulations for what constituted an acceptable overseas ballot, they found that 680 (27\%) of the accepted overseas absentee ballots were flawed. Had these 680 ballots not been accepted, then $52 \%$ of the late overseas absentee ballots would have been rejected in the 2000 Florida election.

The most common flaw found in these ballots was that many had no visible proof of having been mailed by Election Day. Under Florida law, overseas absentee ballots in the 2000 election needed an indication (like a postmark or dated signature) to demonstrate it was mailed before November 7, 2000; 756 ballots did not, and 344 of the counted ballots had this problem. The second type of flaw involved ballots that did not have a witness signature or the witness's complete address; 527 ballots had this flaw, and 96 of the counted ballots were flawed in this way.

The third most significant flaw in the late overseas absentee ballots was that 327 were received after November 7, 2000 with a domestic postmark, and 183 of these ballots were 
counted; Florida law states that absentee ballots that are mailed from within the United States or territories must be received before November 7, 2000. Next, in Florida overseas absentee voters can submit two ballots, and only the second ballot is to be counted; the researchers found 19 instances were both ballots were counted. Last, 69 ballots were received after November 17, 2000 which was the last day overseas absentee ballots could be received (10 days after the election), and 5 of these ballots were counted. From Imai and King's examination of the late overseas absentee ballots from Florida, we see that these ballots contained an extremely high number of errors. Many voters cast ballots that probably should have been rejected.

The Imai and King (2004) study is significant substantively, as it documents major problems with the absentee voting process for this one category of absentee voters. Overseas citizens and military personnel can, just because of the vagaries of both overseas and domestic mail systems, think they voted when in fact their ballot was not counted. Their study is methodologically important as well, because they analyze the actual absentee ballots themselves, and thus know which ballots were counted and which were not. Unfortunately, beyond the Imai and King study, little is known about the resolution of absentee ballots more generally, and about overseas citizen and military absentee ballots specifically. The only attempt at a national study was conducted in 2001 by the GAO, and they prefaced their study by noting that "many counties could not provide data on how many absentee ballots they had received from military and overseas voters covered under the Uniformed and Overseas Citizens Absentee Voting Act and how many of these ballots they had disqualified" (GAO 2001, page 52). Based on partial data, the GAO estimated that $8.1 \%$ of military and overseas absentee ballots were disqualified in 2000 in small counties, relative to a disqualification rate of $1.8 \%$ for other absentee voters. ${ }^{9}$

There are other voting populations that are vulnerable to problems with the absentee voting process. In Los Angeles County, there are six language minorities - Chinese,

\footnotetext{
${ }^{9} \mathrm{GAO} 2001$, page 54. The GAO was unable to provide a national estimate for military and overseas absentee ballot disqualification rates for the larger counties due to unavailability of necessary information from such counties.
} 
Japanese, Korean, Spanish, Tagalog, and Vietnamese - and under the Voting Rights Act of 1965 and its amendments, the county is required to serve these voters in their native language. However, many of these voters also are not used to participating in democratic elections and, even with the outreach efforts of the county and groups assisting language minority voting populations, many find the absentee voting process difficult to navigate. In fact, one of the most common reasons why voters contact the Korean American Coalition's election hotline is to learn more about the election and the general aspects of the voting process (Hall 2002, 2003).

There is research that has studied the political participation by non-foreign born and by non-English proficient citizens. In particular, language proficiency has been shown to be a critical predictor of participation in recent research (e.g., Citrin and Highton 2002, Tam Cho 1999). ${ }^{10}$ A lack of English proficiency can clearly make the process of voting - and in particular absentee voting - more costly and complicated for a citizen (Downs 1957, Tam Cho 1999). This is especially true in the absentee voting process, since biliterate skill development tends to develop slower than bilingual skill development among language minorities. Asian language minorities - of which there are five in Los Angeles County - have an especially difficult time developing biliterate skills because almost all have non-Roman alphabetic writing systems (Loo 1985). This leads us to expect that registered voters who lack English proficiency will also have difficulty navigating the absentee voting process, and that they will be less likely to return their absentee ballots and to have their ballots counted.

Thus, based on the previous studies on absentee voting, we have three hypotheses that we test in this paper. First, we expect that overseas voters will be less likely to return their absentee ballots and will be more likely to have their ballots challenged upon

\footnotetext{
${ }^{10}$ Lien (1994) indirectly studied language use in the home for Asian- and Mexican-Americans and the impact it had on a variety of political participation measures, as in his analysis language use in the home was one of four measures that were collapsed into a single variable called "ethnic ties". In his analysis, he finds that "ethnic ties" do not impact voter turnout for either Asian- or Mexican-Americans; additionally, "ethnic ties" do not impact non-voting participatory activities for Asian-Americans, but stronger "ethnic ties" has a negative and statistically significant impact on non-voting participatory activities for MexicanAmericans.
} 
return. This hypothesis is based on the results found in the GAO report (2001) and Imai and King (2004). Second, we also expect to find that voters who use a non-English ballot will be less likely to return their ballots and will be more likely to have their ballot challenged upon return. We base this hypothesis on the special problems this class of voters faces with the accessibility of the electoral process, and on past research (Tam Cho 1999) that demonstrates that language proficiency is an important predictor of political participation. Last, we expect to find that absentee voters who have applied for an absentee ballot specifically in this election, relative to those who are permanent absentee voters or are in vote-by-mail precincts, will be more likely to return their absentee ballots. This hypothesis is based on the assumption that registered voters who have taken the active step of requesting a ballot for the current election are likely to be more interested in the election and hence more motivated to cast their ballot. We test these hypotheses below using both bivariate and multivariate statistical techniques.

\section{Empirical Results}

We begin with a set of descriptive statistics that summarize the absentee voter file from the 2002 November election in Los Angeles County and the 2000 census data, merged into the file by ZIP Code. ${ }^{11}$ We then turn to some multivariate presentations of the data that test our hypotheses regarding whose absentee ballots are returned and counted. A set of characteristics emerge which are indicative of low return and count rates from these analyses.

In Table 1 we provide descriptive statistics regarding the relative frequencies of each type of absentee voter. "Sample Ballot" absentee voters are ones who applied for their absentee ballot using the form provided in their sample ballot materials that were mailed to their registration address. These absentee voters make up the largest group, at just over $40 \%$ of the absentee voter file. "Permanent" absentee voters are those who have

\footnotetext{
${ }^{11}$ Two groups of absentee voters have been dropped from the analysis. First, as discussed earlier, are the early, touchscreen voters. The second group are those who failed to provide a birth date on their absentee ballot application. This second group comprises 72,421 absentee applications.
} 
requested permanent absentee voting status. In the 2002 general election, these voters made up almost $31 \%$ of those in the absentee voting file. Next were those in the "Apply by Mail" category; these registered voters requested an absentee ballot using some application (most likely provided by a political campaign, party, or interest group), and comprise $23.19 \%$ of those in the absentee voter file. ${ }^{12}$

\section{Table 1 Goes Here}

These three types of absentee voters make up almost $96 \%$ of the absentee voter file in this election in Los Angeles County. The remaining 4\% are almost entirely those who have been classified as "Vote By Mail" voters. The remaining voters are those who have requested an absentee ballot in person ("Walk-in" absentee voters, who are $0.29 \%$ of the absentee voter requests), who are "Overseas" $(0.30 \%)$, or who requested an absentee ballot due to their inability to get to the polling place because of hospitalization or other infirmity (the "Hospital" classification, $0.14 \%$ of absentee voters).

The absentee voter file also contained other valuable information about each individual registered voter: whether they asked for their absentee ballot in English or another available language, their party registration (Democratic, Republican, Third, or Declineto-State), their address, and their birthdate.

\section{Table 2 Goes Here}

In Table 2 we provide the basic descriptive statistics for the registered voters in the absentee voter file. The overwhelming tendency of absentee voters was to request an English ballot - only 3.94\% requested a non-English ballot. The partisan registration of

\footnotetext{
${ }^{12}$ This is an interesting group of voters; many have been contacted specifically in an effort to increase their participation by the party paying for mailings so that this group could vote absentee. In fact, in many states (including California), candidates can ask local election officials for lists of people who have requested absentee ballots. Patterson and Caldiera (1985) find some effects of partisan mobilization in absentee voting rates in Republican counties in Iowa and California in the 1982 election for governor in both of these states, but only in counties with otherwise high Republican support (781). They conclude that efforts to increase absentee voting do have an effect, but that the rates of ballots cast do not favor the Republican party (785). Our data do not allow us to know the exact source of the by-mail absentee ballot application, whether it comes from a partisan source, a specific campaign, or non-partisan sources.
} 
absentee voters in this election was mainly Democratic (about 53\%); Republicans were a third of the file (33\%). Only $2.8 \%$ of the absentee voters were third party registrants, while over $11 \%$ recorded no party affiliation when they registered..$^{13}$ The age distribution of the absentee voters in Table 2 documents a clear skew towards the older age categories. Only $4.3 \%$ of the voters 18 to 25 requested absentee ballots, and a scant $10 \%$ of the 26 to 35 year old voters did as well. However, $25 \%$ of those 35 to 50 requested ballots, $29 \%$ of those 51 to 65 requested absentee ballots, and 32\% of those over the age of 65 .

We also look at the characteristics of the ZIP Codes from which the absentee voters are drawn to gain a sense of which characteristics are associated with more absentee voters. In Table 3, we present the percent of absentee ballot requests from ZIP Codes within a given range of median income. As median income increases, the percentage of voters who are requesting an absentee ballot also increases.

\section{Table 3 Goes Here}

We also include several other characteristics about the ZIP Codes from which the absentee voters are drawn; specifically, the racial breakdown, the percent of residents who have lived in the same house or apartment since 1995, and the percent of residences who have lived in the U.S. since 1995. In Table 4 we present the characteristics of the ZIP Codes from which absentee voters were drawn. Note that this table is different then simply summarizing statistics about Los Angeles County, since the mean is presented by averaging the racial and residential data for each absentee voter, and some ZIP Codes produce more absentee voters than others. The majority of absentee voters are drawn from ZIP Codes where the population is approximately $56 \%$ White, $8 \%$ Black, $1 \%$ American Indian, $13 \%$ Asian, $.25 \%$ Pacific Islander and $16 \%$ other race. Note that there is no classification for Hispanic. Over $50 \%$ of the residents in these ZIP Codes have lived in the same house since 1995 and 42\% have lived in the U.S. since at least 1995.

\footnotetext{
${ }^{13}$ In the 2002 general election in Los Angeles County, the larger pool of registered voters was 52.27\% Democratic, $27.57 \%$ Republican, $15.19 \%$ "decline to state"', and $4.97 \%$ other parties. Thus, the set of absentee voters requesting ballots in this election was somewhat more likely to be Republican than the overall pool of registered voters.
} 


\section{Table 4 Goes Here}

We continue looking at the basic attributes of absentee voters by considering the way in which they requested an absentee ballot. In Table 5, we present two panels of information: the top panel provides ballot request breakdowns for language use and partisanship, and the bottom panel provides the same breakdowns for the age distributions. Of the 15,308 absentee voters who requested a non-English ballot, almost $41 \%$ did so using the form provided in their sample ballot. Additionally, 35\% of the non-English registered voters in the absentee voter file are permanent absentee voters, while another $21 \%$ applied by mail.

\section{Table 5 Goes Here}

In terms of partisanship, there were 206,400 absentee voters with a Democratic party affiliation. Breaking down this number by ballot type, Democratic absentee voters were roughly one-third permanent absentee voters, one-third used their sample ballot application, and one-third applied by mail. Republican absentee voters were much more likely to use the sample ballot application (48\%) and almost one-third of Republican absentee voters were permanently registered as absentee. Many fewer Republicans than Democrats applied by mail. The decline-to-state (a party preference) and third party absentee voters demonstrate a profile much like Republicans: $47 \%$ of the decline-to-state voters used the sample ballot application, one-third were permanent absentee voters, and $14 \%$ applied by mail. The profile of third party absentee voters looks very similar. Both decline-to-state and third party absentee voters were about twice as likely to be in vote-by-mail precincts or to be overseas absentee voters. The discrepancy between the percentage of Republicans and Democrats who use the sample ballot application could be attributed to different techniques of party mobilization (Leighley 2001) but further investigation into the effects of party affiliation yields no increase in return or count rates, at least for permanent absentee voters. 
The bottom panel of Table 5 gives the same ballot request breakdowns by age. Of younger voters (18-25 years of age), almost $44 \%$ used the sample ballot to get their absentee ballot, $34 \%$ applied by mail, and $12 \%$ were permanent absentee voters. The percentage use of the sample ballot application decreases slightly for 26-35 year olds, as does the use of general absentee ballot request by mail. This age group is more likely to be permanent absentee voters. In older age brackets, the use of the sample ballot is still prevalent with more and more voters tending to be permanent absentee voters. Absentee voters over age 65 are very likely be be permanent absentee voters (46\%) and are less likely to have used the sample ballot or other by-mail means to get their absentee ballot.

Next we turn to the question of absentee ballot resolution. For every individual in the November 2002 absentee voter file we know (1) whether the individual returned their ballot, and (2) if they returned their ballot, whether it was challenged or counted. We give the simple statistics for the entire absentee voter population in Table 6.

\section{Table 6 Goes Here}

In this particular election, almost one-quarter $(24.75 \%)$ of the absentee ballots requested were not returned by voters. Once returned, an additional $4 \%$ were returned and challenged (thus not counted). The way in which these challenged ballots were adjudicated could have a significant impact on many races. The percent of returned ballots that were not counted was $5.47 \%$ in this election, a margin large enough to possibly affect outcomes.

The next two tables provide descriptive information regarding whether individual ballots are returned and are counted, based on ballot request mechanisms and voter characteristics. In Table 7, we give the ballot resolution statistics for the eight different types of absentee voters. This table shows the percentage for each type of absentee voter who (1) did not return their ballot, (2) returned their ballot and their ballot was counted, and (3) returned their ballot but it was challenged and not included in the vote tabulation. The voters most likely not to return their ballot were those in vote-by-mail precincts $(59.88 \%)$, overseas voters $(49.41 \%)$, and permanent absentee voters $(34.85 \%)$. Voters who are hospitalized, who requested an absentee ballot in person, or who used a sample ballot are much 
more likely to return their ballot. The absentee voter categories which are less likely to return their ballot are also more likely to have that ballot challenged - overseas voters have almost $10 \%$ of their ballots challenged and not counted. Those in vote-by-mail precincts also have high challenge rates $(8 \%)$. At the other end of the distribution are walk-in and sample ballot absentee voters, with about $2 \%$ of each of their returned ballots challenged.

\section{Table 7 Goes Here}

In Table 8, we present ballot resolution rates for the variables we have for each citizen in the absentee voter file: language, partisanship, and age. Again, we look first at ballot returns and then at whether the ballot is challenged and not counted. Beginning with ballot language, we see that non-English absentee voters are slightly more likely to not return their ballot, and marginally more likely to have their ballot challenged if returned. Amongst the partisan groupings, about one-third of third party or decline-to-state absentee voters did not return their absentee ballots, between five and ten percentage points higher than for either Democrats or Republicans. Furthermore, third party and declineto-state voters are marginally more likely to have their absentee ballots challenged and not included in the tabulation than are Democrats or Republicans. Younger voters are also more likely to fail to return their ballot and once returned, less likely to have their ballot counted compared to older voters.

\section{Table 8 Goes Here}

We next examine ballot resolution rates for the variables we have for each ZIP Code, looking at the number of ballots returned and then challenged and not counted. Although no conclusions can be drawn at an individual level by presenting these statistics, they do provide an intuition for which groups of absentee voters are least likely to have their ballot counted. In Table 9, we examine the return and challenge rates by ZIP Code median income. As median income increases, the percent of unreturned ballots out of those requested decreases dramatically. There is also a decrease of a little more than $1 \%$ in the 
challenge rates as the median income increases from the lowest to the highest median household income.

\section{Table 9 Goes Here}

Thus far we have only examined relatively simple summary statistics. We cannot say with much certainty whether some absentee voter types are more or less likely to return their absentee ballots (for example) than others without using a multivariate statistical analysis. We now turn to a multivariate logit analysis to better examine our hypothesis. We are interested in modeling the two-part process we have been calling ballot resolution: (1) whether an individual returns their absentee ballot or not, and then (2) whether the returned ballot is challenged or counted. Our approach here is to examine each component of this ballot resolution process independently. That is, we specify a dependent variable with three possible values; an indicator of 1 if the ballot was returned and counted, 2 if the ballot was returned but not counted, and 3 if the ballot was not returned. We then present coefficients holding one event as the baseline, so that the coefficients presented are in comparison to the effect on the constant event.

In our multivariate logit model, we use the event coded as a 1, that the ballot was returned and counted, as a baseline. We include indicator variables for the various types of absentee voters: UOCAVA, Sample Ballot, In-person, Hospital, and Permanent absentee voters. We also include an indicator variable for whether or not the absentee voter requested an English language ballot, for partisanship (Democrat, Republican, and Declineto-state), and for the voter's age. ${ }^{14}$ Finally, we include ZIP Code statistics, such as the percent white, percent black, the median income, the percent of residents who have been living in the U.S. since 1995, and the percent of residents living in the same house since 1995. These ZIP Code statistics are included as control variables.

Table 10 shows the multinomial logit analysis of absentee ballot return. The table is organized with each independent variable in a column followed by the estimated model

\footnotetext{
${ }^{14}$ Note that any observation with a missing data point is dropped from the analysis; in our case we have approximately seventy-two thousand observations for which we lack the information required to compute the voter's age. As a consequence these observations are dropped from the estimation.
} 
coefficient for the event coded as a 2 (when the ballot was returned and not counted), followed by the estimated model coefficient for the event coded as a 3 (when the ballot was not returned). Below each coefficient is the estimated standard error. Interpreting these results is a bit complicated; when looking at the coefficients it is important to remember that their directionality is in reference to the outcome coded as 1, when the ballot is returned and counted. Therefore, a positive coefficient in either of these two columns implies that as the independent variable increases, the absentee voter is less likely to return their ballot (the third column) or to have their ballot counted (the second column).

For ease of interpretation, we recalculate the coefficients from the multinomial logit as relative risk ratios (RRR) in Table 11. This table presents each coefficient raised exponentially, which is interpreted as the ratio of relative risk - that is, the effect for a one-unit change in the variable relative to the arbitrarily chosen base category (in this case, returned and counted). For example, the RRR of being a UOCAVA voter for returned and not counted ballots is interpreted as for a one-unit increase in UOCAVA voters, the number of ballots returned and not counted will increase compared to the base category of the number of ballots returned and counted. Note that when examining these terms, an RRR of 1 implies the value of the coefficient is zero (or in this case, was rounded to zero).

\section{Tables 10 and 11 Go Here}

Considering the presented in Table 10, note that UOCAVA voters, permanent absentee voters, and all age groups except the excluded category (age 65 and older) are less likely to return their ballots. Furthermore, voters who have requested a non-English ballot are also less-likely to return their ballot (since the English coefficient is negative, the non-English coefficient will therefore be positive). Surprisingly, two unlikely ZIP Code statistics are also related to lower return rates - the percent of residences who have lived in the same house since 1995 and the percent of residents who have been in the United States at least since 1995. This would suggest that voters who live in ZIP Codes with a more mobile population with a higher percentage of immigrants is more likely to return their ballots, 
while controlling for ballots requested in languages other than English. One possible explanation of the sign of these coefficients is that they may be correlated with latent variables associated with permanent absentee ballots mailed to voters no longer residing at that address.

Looking at the characteristics which are related to lower count rates, UOCAVA voters, permanent absentee voters, non-English voters, and all age groups have a lower likelihood of having their ballot counted once returned. These are all conclusions consistent with our initial hypothesis. In terms of ZIP Code coefficients, the percentage of black residents in a ZIP Code is related to a lower count rate. Unlike the return rate coefficients, the percent of residents who have lived in in the same house since 1995 and the percent of residents who have lived in the U.S. since 1995 are not related to lower count rates. This result is consistent with the explanation that these ZIP Code statistics are correlated with permanent absentee ballots mailed to voters no longer residing at the same address.

\section{Conclusion}

Increasing numbers of Americans are turning to absentee voting, especially voting by mail. Absentee voting is undoubtedly a more convenient way for many citizens to participate in the electoral process, and election administrators increasingly favor it because it reduces the number of citizens using traditional polling places to vote. There have been a number of studies that have looked at the recent rise in absentee voting. This literature has focused on the impact of voting by mail, either by looking at the effects that absentee voting has on voter turnout or the effects it has on the composition of the electorate. There have been a number of studies that have looked at the recent rise in absentee voting. This literature has focused on the impact of voting by mail, either by looking at the effects that absentee voting has on voter turnout or the effects it has on the composition of the electorate. Our study is different, as we have a unique dataset that allows us to study whether absentee votes were counted.

The first step in the absentee voting process is the return of the ballot. We found that 
overseas citizens, permanent absentees, and those citizens who requested a non-English ballot were substantially less likely to return their absentee ballot. That these groups are less likely to return their ballots indicates that they face significant hurdles as they attempt to participate in the political process. While we do not have information in our dataset that will allow us to better understand why these two groups are less likely to return their ballots, we speculate that the overseas voters are undoubtedly facing the sorts of difficulties highlighted in studies following the 2000 presidential election: the significant amount of time that it can take for voting materials to be mailed and to be returned. Language minority voters, by contrast, may find casting their absentee ballot difficult because of a lack of understanding about the balloting process.

The second step, whether or not the absentee ballot gets counted once it is returned by the voter, also produced an intriguing result. We found that overseas voters were substantially more likely to have their absentee ballot challenged and not counted than other types of absentee voters. Again, we do not have specific information about why overseas ballots were more likely to be challenged, although we speculate that they are challenged because they are coming in after the official deadline in California - the close of polling on Election Day. The GAO study (2001) found that, in counties that provided disqualified ballot data for military and overseas citizens, approximately $40 \%$ of the disqualified ballots arrived after the legal deadline for absentee voting. In some states, such as Florida, consideration is made for the ballot transit problems encountered by UOCAVA voters. There, the deadline for receipt of absentee ballots is 10 days after the election. By examining the post marks on challenged and uncounted absentee ballots, it would be possible to determine how many ballots would have been counted under various deadline extensions. This policy change also might encourage more UOCAVA voters to return ballots in the first place.

It is also likely that overseas absentee ballots are being challenged due to other defects, like missing information on the return envelope. Language minority voters may also be making errors on their absentee ballot return envelop that result in the ballot being 
challenged. Unfortunately, the database we were provided does not indicate why ballots were challenged..$^{15}$

Again, as stated above, race, income, and length of residence play very small, if any, role in determining whether or not a ballot is returned or counted controlling for the type of absentee ballot. This again leads to the conclusion that ballot type is a factor in determining these outcomes.

We must be cautious in generalizing our results in this paper as we are only studying one election in one California county. It will be interesting to study other elections in Los Angeles County, as well as other states and counties, using the actual absentee voter files. These databases provide a wealth of important information, especially concerning the administrative issues of who returns their absentee ballots and whose absentee ballots are counted.

The 2000 presidential election generated enormous interest in the basic questions of election administration in the United States. Most of these studies, like the Caltech/MIT study that estimated that as many as 6 million votes were "lost" in the election, have studied polling place and voting system problems. As increasing number of Americans participate using the absentee voting process, we clearly need to better understand how the absentee voting process works, who uses it, and what problems certain types of voters might encounter as they attempt to participate using the absentee voting process.

\section{References}

John H. Aldrich, 1993. "Rational Choice and Turnout." American Journal of Political Science 37: 246-278.

Alvarez, R. Michael and Betsy Sinclair. 2004. Who Overvotes, Who Undervotes, Using

\footnotetext{
${ }^{15}$ The absentee voting file from the 2002 November election does have a field that indicates the date of ballot return. $90.5 \%$ of the challenged UOCAVA absentee ballots arrived after the legal deadline for absentee voting. However, there are some apparent inaccuracies with data entered into this field, as it appears that there are 1114 absentee ballots with return dates after the close of election that were returned and not challenged. Discussions with Los Angeles County Registrar-Recorder staff indicated that this discrepancy arises from inaccuracies in data entry.
} 
Punchcards? Evidence from Los Angeles County. Political Research Quarterly.

Ansolabehere, Stephen. 2002. Voting Machines, Race, and Equal Protection. Election Law Journal 1: 61-70.

American Political Science Association. 1952. Findings and Recommendations of the Special Committee on Service Voting. American Political Science Review. 46, 2: 512-523.

Barstow, David and Don Van Natta, Jr. 2001. How Bush Took Florida: Mining the Overseas Absentee Vote, New York Times, Sunday July 15, 2001, page 1.

Berinsky, Adam J., Nancy Burns, and Michael W. Traugott. 2001. Who Votes by Mail? A Dynamic Model of the Individual-Level Consequences of Voting-by-Mail Systems. Public Opinion Quarterly, 178-197.

Caltech/MIT Voting Technology Project. 2001. Voting: What Is, What Could Be. Pasadena, CA and Cambridge, MA. http://www.vote.caltech.edu.

Citrin, Jack and Benjamin Highton. 2002. How Race, Ethnicity, and Immigration Shape the California Electorate. San Francisco, California: Public Institute Policy of California.

Downs, Anthony. 1957. An Economic Theory of Democracy. New York: Harper and Row.

Dubin, Jeffrey A. and Gretchen A. Kalsow. 1996a. Comparing Absentee and Precinct Voters: Voting on Direct Legislation. Political Behavior. 18, 4: 393-411.

Dubin, Jeffrey A. and Gretchen A. Kalsow. 1996b. Comparing Absentee and Precinct Voters: A View Over Time. Political Behavior. 18, 4: 369-392.

Gans, Curtis. 2000. Mobilization Propels Modest Turnout Increase GOP Out Organizes Democrats: Registration Lower, Parties In Trouble, Reforms Fail to Boost Turnout. Committee for the Study of the American Electorate. http://www.gspm.org/csae/cgans9.html 
General Accounting Office. 2001. Elections: Voting Assistance to Military and Overseas Citizens Should Be Improved. GAO-01-1026.

Hall, Thad E. Forthcoming. Public Participation in Election Management: The Case of Language Minority Voters. American Review of Public Administration.

Hall, Thad E. 2002. LA Story: The 2001 Election. A Century Foundation Report. New York: The Century Foundation.

Imai, Kosuke, and King, Gary. "Did Illegal Overseas Absentee Ballots Decide the 2000 U.S. Presidential Election?" Perspectives on Politics, Vol. 2, No. 3 (September 2004), pp 537-549.

Lieb, David A. "In close election year, political parties taking advantage of state laws to contact absentee voters directly", The Associated Press, October 21, 2004.

Karp, Jeffrey A. and Susan A. Banducci. 2000. Going Postal: How All Mail Elections Influence Turnout. Political Behavior. 22, 3: 223-239.

Keyssar, Alexander. 2000. The Right to Vote: The Contested History of Democracy in the United States. New York: Basic Books.

Kim, Jae-On, John R. Petrocik, and Stephen N. Enokson. 1975. Voter Turnout Amongst the American States: Systemic and Individual Components. American Political Science Review 69: 107-123.

King, Gary, Michael Tomz, and Jason Wittenberg. 2000. Making the Most of Statistical Analysis: Improving Interpretation and Presentation. American Journal of Political Science 44: 347-61.

Lien, Pei-te. 1994. Ethnicity and Political Participation: A Comparison Between Asian and Mexican Americans. Political Behavior 16: 237-264. 
Loo, Chalsa M. 1985. The Biliterate Ballot Controversy: Language Acquisition and Cultural Shift among Immigrants. International Migration Review. 19, 3: 493-515.

Martin, Boyd A. 1945. The Service Vote in the Elections of 1944. American Political Science Review. 39, 4: 720-732.

Oliver, J. Eric. 1996. The Effects of Eligibility Restrictions and Party Activity on Absentee Voting and Overall Turnout. American Journal of Political Science. 40, 2: 498-513.

Ornstein, Robert. 2001. The Dangers of Voting Outside the Booth. The New York Times, August 3, 2001.

Patterson, Samuel C. and Caldeira, Gregory A. "Mailing in the Vote: Correlates and Consequences of Absentee Voting", American Journal of Political Science, Vol. 29, No. 4 (Nov. 1985), 766-788.

Ray, P. Orman. 1926. Absent-Voting Legislation, 1924-1925. American Political Science Review. 20, 2: 347-349.

Ray, P. Orman. 1919. Recent Primary and Election Laws. American Political Science Review. 12, 3: 461-469.

Ray, P. Orman. 1918a. Military Absent-Voting Laws. American Political Science Review. 13, 2: $264-274$.

Ray, P. Orman. 1918b. Absent-Voting Laws, 1917. American Political Science Review. 12, 2 : 251-261.

Ray, P. Orman. 1914. Absent Voters. American Political Science Review. 8, 3: 442-445.

Rosenstone, Steven J., and Mark Hansen. 1993. Mobilization, Participation, and Democracy in America. New York: Macmillan Publishing Company. 
Southwell, Priscilla L. and Justin Burchett. 1997. Survey of Vote-by-Mail Senate Election in the State of Oregon. PS, Political Science and Politics. March: 53-57.

Southwell, Priscilla L. and Justin Burchett. 2000b. Does Changing the Rules Change the Players? Vote-by-Mail and the Composition of the Electorate, Social Science Quarterly. 81, 4: 837-845.

Southwell, Priscilla L., and Justin I. Burchett. 2000a. The Effect of All-Mail Elections on Voter Turnout. American Politics Research. 28, 1: 72-79.

Stein, Robert. 1998. Early Voting. Public Opinion Quarterly 62: 57-70.

Stein, Robert and Patricia Garcia-Money. 1997. Voting Early, But Not Often. Social Science Quarterly 78: 657-677.

Steinbicker, Paul G. 1938. Absentee Voting in the United States. American Political Science Review 23: 898-907.

Tam Cho, Wendy K. 1999. Naturalization, Socialization, and Participation: Immigrants and (Non-) Voting. Journal of Politics 61: 1140-55.

Tomz, Michael, Jason Wittenberg, and Gary King. 2003. Clarify: Software for Interpreting and Presenting Statistical Results. Version 2.1. Stanford University, University of Wisconsin, and Harvard University. January 5. Available at http://gking.harvard.edu/.

Tomz, Michael and Robert P. Van Houweling, 2003. How Does Voting Equipment Affect the Race Gap in Voided Ballots? American Journal of Political Science 47, 46-60.

United States Census Bureau, Department of Commerce, Economics and Statistics Administration. 2002. Voting and Registration in the Election of November 2002. http:/ / www.census.gov/ 542.pdf.

Winther, Oscar Osburn. 1944. The Soldier Vote in the Election of 1864. New York History. 25: 440-458. 
Wolfinger, Raymond E. and Stephen J. Rosenstone. 1980. Who Votes. New Haven: Yale University Press. 


\section{Tables}

Table 1: Types of Absentee Ballots

\begin{tabular}{|l|c|c|}
\hline \hline Type & Percent & Number \\
\hline Sample Ballot & 40.67 & 157,931 \\
Permanent & 31.63 & 122,830 \\
Apply by Mail & 23.19 & 90,069 \\
Vote by Mail & 3.76 & 14,618 \\
Walk-in & 0.29 & 1,141 \\
Overseas & 0.3 & 1,182 \\
Hospital & 0.14 & 555 \\
\hline Total & 100 & 388,326 \\
\hline
\end{tabular}

Table 2: Some Characteristics of Absentee Voters

\begin{tabular}{|l|c|}
\hline \hline Characteristics & Percent \\
\hline Language & \\
\hline English & 96.06 \\
Non-English & 3.94 \\
\hline Party Registration & \\
\hline Democratic & 53.15 \\
Republican & 32.59 \\
Third Party & 2.82 \\
Decline to State & 11.44 \\
\hline Age & \\
\hline 18-25 & 4.30 \\
25-35 & 9.54 \\
$35-50$ & 24.80 \\
$50-65$ & 29.75 \\
$65+$ & 31.63 \\
\hline
\end{tabular}


Table 3: Absentee Ballot Requests by Median Income

\begin{tabular}{|l|c|c|c|c|}
\hline \hline $\begin{array}{l}\text { Income Range } \\
\text { (in \$ thousands) }\end{array}$ & Zip Codes & Requested Ballots & Population & Percent \\
\hline $0-10$ & 2 & 470 & 13,194 & 3.56 \\
$10-20$ & 6 & 2,676 & 131,132 & 2.04 \\
$20-30$ & 33 & 36,340 & $1,495,791$ & 2.94 \\
$30-40$ & 64 & 82,269 & $2,791,439$ & 3.95 \\
$40-50$ & 62 & 85,385 & $2,160,726$ & 3.95 \\
$50-60$ & 45 & 69,732 & $1,344,667$ & 5.19 \\
$60-70$ & 30 & 53,619 & 920,514 & 5.82 \\
$70-80$ & 11 & 17,455 & 277,986 & 6.28 \\
$80-90$ & 11 & 13,033 & 195,931 & 6.65 \\
$90-100$ & 2 & 6,123 & 65,076 & 9.41 \\
$100-110$ & 4 & 7,858 & 87,245 & 9.01 \\
$110-120$ & 4 & 7,608 & 70,934 & 10.73 \\
$120-130$ & 1 & 2,124 & 22,636 & 9.38 \\
$130-140$ & 0 & 0 & 0 & 0 \\
$140-150$ & 1 & 877 & 10,473 & 8.37 \\
\hline
\end{tabular}

Table 4: Characteristics of ZIP Codes

\begin{tabular}{|l|c|}
\hline \hline Variable & Mean Percent \\
\hline White & 55.72 \\
Black & 8.49 \\
American Indian & .62 \\
Asian & 13.00 \\
Pacific Islander & .25 \\
Other & 16.89 \\
Same House Since '95 & 52.88 \\
In US Since '95 & 42.62 \\
\hline \hline
\end{tabular}


Table 5: Characteristics of Absentee Voters by Ballot Type

\begin{tabular}{|l|c|c|c|c|c|}
\hline \hline Language \& Party & & & & & \\
\hline Ballot Type & Non-English & Democratic & Republican & DTS & Third \\
\hline Sample Ballot & 40.57 & 33.98 & 48.48 & 47.32 & 49.54 \\
Permanent & 34.81 & 31.8 & 31.34 & 32.06 & 29.98 \\
Apply by Mail & 20.60 & 29.74 & 16.6 & 14.00 & 13.23 \\
Vote by Mail & 3.36 & 3.73 & 2.93 & 5.69 & 6.25 \\
Walk-in & 0.57 & 0.32 & 0.26 & 0.25 & 0.34 \\
Overseas & 0.03 & 0.26 & 0.27 & 0.56 & 0.46 \\
Hospital & 0.05 & 0.17 & 0.11 & 0.10 & 0.20 \\
\hline Total & 15,308 & 206,400 & 126,553 & 44,421 & 10,962 \\
\hline \hline Age & & & & & \\
\hline Ballot Type & $18-25$ & $25-35$ & $35-50$ & $50-65$ & $65+$ \\
\hline Sample Ballot & 43.87 & 40.29 & 43.66 & 44.00 & 34.87 \\
Permanent & 11.71 & 20.91 & 24.08 & 29.35 & 45.64 \\
Apply by Mail & 34.31 & 29.95 & 26.84 & 22.94 & 17.03 \\
Vote by Mail & 8.22 & 7.66 & 4.67 & 3.11 & 1.89 \\
Walk-in & 0.33 & 0.29 & 0.31 & 0.34 & 0.23 \\
Overseas & 1.47 & 0.77 & 0.34 & 0.17 & 0.10 \\
Hospital & 0.08 & 0.11 & 0.10 & 0.10 & 0.24 \\
\hline Total & 16,681 & 37,029 & 96,286 & 115,511 & 122,819 \\
\hline
\end{tabular}

Table 6: Absentee Ballot Resolution

\begin{tabular}{|l|c|c|}
\hline \hline Resolution & Percent & Number \\
\hline Not Returned & 24.75 & 96,115 \\
Returned and Not Challenged & 71.34 & 277,046 \\
Returned and Challenged & 3.91 & 15,165 \\
\hline Total & 100 & 388,326 \\
\hline
\end{tabular}


Table 7: Ballot Resolution by Absentee Voter Type

\begin{tabular}{|l|c|c|c|c|}
\hline \hline Ballot Type & $\begin{array}{c}\text { Percent Not } \\
\text { Returned }\end{array}$ & $\begin{array}{c}\text { Percent Not } \\
\text { Challenged }\end{array}$ & $\begin{array}{c}\text { Percent } \\
\text { Challenged }\end{array}$ & Total \\
\hline Sample Ballot & 14.64 & 82.60 & 2.76 & 157,931 \\
Permanent & 34.85 & 60.41 & 4.75 & 122,839 \\
Apply by Mail & 23.02 & 73.06 & 3.92 & 90,069 \\
Vote by Mail & 59.88 & 31.37 & 8.75 & 14,618 \\
Walk-in & 9.20 & 88.34 & 2.45 & 1,141 \\
Overseas & 49.41 & 41.12 & 9.48 & 1,182 \\
Hospital & 1.80 & 93.51 & 4.68 & 555 \\
\hline \hline
\end{tabular}

Table 8: Ballot Resolution by Absentee Voter Characteristics

\begin{tabular}{|l|c|c|c|c|}
\hline \hline Characteristic & $\begin{array}{c}\text { Percent Not } \\
\text { Returned }\end{array}$ & $\begin{array}{c}\text { Percent Not } \\
\text { Challenged }\end{array}$ & $\begin{array}{c}\text { Percent } \\
\text { Challenged }\end{array}$ & Total \\
\hline English & 24.66 & 71.45 & 3.90 & 373,018 \\
Non-English & 27.02 & 68.84 & 4.14 & 15,308 \\
Democratic & 25.52 & 70.48 & 3.99 & 206,400 \\
Republican & 20.90 & 75.47 & 3.63 & 126,553 \\
Third Party & 29.57 & 65.83 & 4.59 & 10,952 \\
DTS & 30.96 & 64.94 & 4.10 & 44,421 \\
18-25 & 42.00 & 51.55 & 4.72 & 16,681 \\
25-35 & 36.61 & 58.68 & 4.72 & 37,029 \\
$35-50$ & 27.84 & 68.11 & 4.06 & 96,286 \\
$50-65$ & 20.53 & 75.98 & 3.49 & 115,511 \\
$65+$ & 20.38 & 76.03 & 3.59 & 122,819 \\
\hline
\end{tabular}


Table 9: Ballots Returned and Not Counted by Income

\begin{tabular}{|l|c|c|c|c|}
\hline \hline $\begin{array}{l}\text { Income Range } \\
\text { (nn thousands) }\end{array}$ & $\begin{array}{c}\text { Percent Not } \\
\text { Returned }\end{array}$ & $\begin{array}{c}\text { Percent Not } \\
\text { Challenged }\end{array}$ & $\begin{array}{c}\text { Percent } \\
\text { Challenged }\end{array}$ & Total \\
\hline $0-10$ & 26.17 & 68.94 & 4.89 & 470 \\
$10-20$ & 31.39 & 62.29 & 6.32 & 2,676 \\
$20-30$ & 30.32 & 65.11 & 4.57 & 36,340 \\
$30-40$ & 27.03 & 68.62 & 4.35 & 84,088 \\
$40-50$ & 25.09 & 71.04 & 3.87 & 86,321 \\
$50-60$ & 23.48 & 72.89 & 3.63 & 69,732 \\
$60-70$ & 21.15 & 75.39 & 3.45 & 53,619 \\
$70-80$ & 23.83 & 72.82 & 3.35 & 17,455 \\
$80-90$ & 20.81 & 75.71 & 3.48 & 13,033 \\
$90-100$ & 21.67 & 75.06 & 3.27 & 6,123 \\
$100-110$ & 21.99 & 74.20 & 3.81 & 7,858 \\
$110-120$ & 20.85 & 75.29 & 3.86 & 7,608 \\
$120-130$ & 17.18 & 79.47 & 3.34 & 2,124 \\
$130-140$ & NA & NA & NA & 0 \\
$140-150$ & 17.33 & 79.13 & 3.53 & 877 \\
\hline
\end{tabular}


Table 10: Multinomial Logistic Regression Coefficients

\begin{tabular}{|c|c|c|}
\hline Variable & Returned, Not Counted Coeff & Not Returned Coeff \\
\hline \multirow[t]{2}{*}{ UOCAVA } & $1.04^{*}$ & $.83^{*}$ \\
\hline & (.11) & $(.06)$ \\
\hline \multirow[t]{2}{*}{ Sample Ballot } & $-.67^{*}$ & $-.80^{*}$ \\
\hline & $(.02)$ & $(.01)$ \\
\hline \multirow{2}{*}{ In-Person } & $-.87^{*}$ & $-1.4^{*}$ \\
\hline & (.19) & $(.1)$ \\
\hline \multirow[t]{2}{*}{ Hospital } & -.21 & $-2.94^{*}$ \\
\hline & $(.20)$ & $(.32)$ \\
\hline \multirow[t]{2}{*}{ Permanent } & $.30^{*}$ & $.54^{*}$ \\
\hline & $(.02)$ & $(.01)$ \\
\hline \multirow{2}{*}{ English } & $-.16^{*}$ & $-.15^{*}$ \\
\hline & $(.04)$ & $(.02)$ \\
\hline \multirow[t]{2}{*}{ Democrat } & $-.24^{*}$ & -.23 \\
\hline & $(.05)$ & $(.02)$ \\
\hline \multirow[t]{2}{*}{ Republican } & $-.24^{*}$ & $-.33^{*}$ \\
\hline & $(.05)$ & $(.02)$ \\
\hline \multirow[t]{2}{*}{ Decline } & $-.12^{*}$ & .04 \\
\hline & $(.05)$ & $(.02)$ \\
\hline \multirow[t]{2}{*}{ Age 18-25 } & $1.18^{*}$ & $1.39^{*}$ \\
\hline & $(.04)$ & $(.02)$ \\
\hline \multirow[t]{2}{*}{ Age 25-35 } & $.66^{*}$ & $1.04^{*}$ \\
\hline & (.03) & $(.01)$ \\
\hline \multirow[t]{2}{*}{ Age $35-50$} & $.38^{*}$ & $.63^{*}$ \\
\hline & $(.02)$ & $(.01)$ \\
\hline \multirow[t]{2}{*}{ Age 50-65 } & $.10^{*}$ & $.17^{*}$ \\
\hline & $(.02)$ & $(.01)$ \\
\hline \multirow[t]{2}{*}{ Per. White } & .001 & $-.01^{*}$ \\
\hline & $(.001)$ & $(.0004)$ \\
\hline \multirow[t]{2}{*}{ Per. Black } & $.006^{*}$ & $-.006^{*}$ \\
\hline & $(.001)$ & $(.0004)$ \\
\hline \multirow[t]{2}{*}{ Median Income } & $.000^{*}$ & $-.000^{*}$ \\
\hline & (.000) & $(.000)$ \\
\hline \multirow[t]{2}{*}{ Per. Same House '95 } & $-.03^{*}$ & $.01^{*}$ \\
\hline & $(.004)$ & $(.002)$ \\
\hline \multirow{2}{*}{ Per. US '95 } & $-.02^{*}$ & $.013^{*}$ \\
\hline & $(.004)$ & $(.002)$ \\
\hline Observations & 388,326 & \\
\hline
\end{tabular}


Table 11: Multinomial Logistic Regression Coefficients, reported as Relative Risk Ratios

\begin{tabular}{|c|c|c|}
\hline Variable & Returned, Not Counted RRR & Not Returned RRR \\
\hline UOCAVA & $2.83^{*}$ & $2.29^{*}$ \\
\hline & $(.30)$ & (.15) \\
\hline Sample Ballot & $.51^{*}$ & $.44^{*}$ \\
\hline & $(.01)$ & $(.004)$ \\
\hline In-Person & $\begin{array}{l}.42^{*} \\
(.08)\end{array}$ & $\begin{array}{l}.24^{*} \\
(.02)\end{array}$ \\
\hline Hospital & $\begin{array}{c}.81 \\
(.16)\end{array}$ & $\begin{array}{l}.05^{*} \\
(.01)\end{array}$ \\
\hline Permanent & $\begin{array}{l}1.35^{*} \\
(.03)\end{array}$ & $\begin{array}{l}1.72^{*} \\
(.02)\end{array}$ \\
\hline English & $\begin{array}{l}.85^{*} \\
(.04)\end{array}$ & $\begin{array}{l}.85^{*} \\
(.02)\end{array}$ \\
\hline Democrat & $\begin{array}{l}.78^{*} \\
(.04)\end{array}$ & $\begin{array}{l}.77^{*} \\
(.02)\end{array}$ \\
\hline Republican & $\begin{array}{l}.78^{*} \\
(.04)\end{array}$ & $\begin{array}{l}.70^{*} \\
(.02)\end{array}$ \\
\hline Decline & $\begin{array}{c}.89^{*} \\
(.05)\end{array}$ & $\begin{array}{l}1.00 \\
(.02)\end{array}$ \\
\hline Age 18-25 & $\begin{array}{l}3.24^{*} \\
(.12)\end{array}$ & $\begin{array}{l}4.03^{*} \\
(.08)\end{array}$ \\
\hline Age 25-35 & $\begin{array}{l}1.94^{*} \\
(.06)\end{array}$ & $\begin{array}{l}2.83^{*} \\
(.04)\end{array}$ \\
\hline Age 35-50 & $\begin{array}{l}1.47^{*} \\
(.02)\end{array}$ & $\begin{array}{l}1.89^{*} \\
(.02)\end{array}$ \\
\hline Age 50-65 & $\begin{array}{l}1.10^{*} \\
(.02)\end{array}$ & $\begin{array}{l}1.19^{*} \\
(.01)\end{array}$ \\
\hline Per. White & $\begin{array}{l}1.00^{*} \\
(.001)\end{array}$ & $\begin{array}{c}1.00^{*} \\
(.0003)\end{array}$ \\
\hline Per. Black & $\begin{array}{l}1.01^{*} \\
(.001)\end{array}$ & $\begin{array}{c}1.00^{*} \\
(.0003)\end{array}$ \\
\hline Median Income & $\begin{array}{l}1.00^{*} \\
(.000)\end{array}$ & $\begin{array}{l}1.00^{*} \\
(.000)\end{array}$ \\
\hline Per. Same House '95 & $\begin{array}{c}.97^{*} \\
(.001)\end{array}$ & $\begin{array}{c}1.00^{*} \\
(.0004)\end{array}$ \\
\hline Per. US '95 & $\begin{array}{c}.98^{*} \\
(.001)\end{array}$ & $\begin{array}{c}.99^{*} \\
(.001)\end{array}$ \\
\hline Observations & 388,326 & \\
\hline
\end{tabular}

